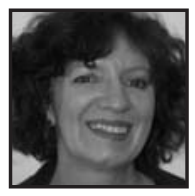

\title{
Inhabiting Silence: A Sorry Story
}

\author{
Susanne Gannon, University of Western Sydney
}

\section{ABSTRACT}

This paper describes how works created in a visual arts workshop enable the author to work obliquely with stories about teaching Aboriginal children generated in a collective biography. The deconstructive work is framed by Prime Minister Rudd's 2008 "sorry" speech to Aboriginal Australians and Mazzei's work on silence with white teachers. The visual arts methodology allows a shift from narrative logic and literal detail to metonymy and symbolism while the materiality of artefacts and art equipment invite particular representations and interpretations to emerge.

For the pain, suffering and hurt of these Stolen Generations, their descendants and for their families left behind, we say sorry.

To the mothers and the fathers, the brothers and the sisters, for the breaking up of families and communities, we say sorry.

And for the indignity and degradation thus inflicted on a proud people and a proud culture, we say sorry.... To the Stolen Generations,

I say the following: as Prime Minister of Australia, I am sorry.

On behalf of the Government of Australia, I am sorry.

On behalf of the Parliament of Australia, I am sorry.

(Rudd, 2008, italics added)

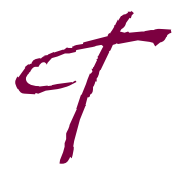

his paper is, in a way, my own sorry story. I write it several months after new Prime Minister Kevin Rudd opened the Australian Federal Parliament with the apology for which we had waited eleven years since the publication of the Bringing Them Home report (Human Rights and Equal Opportunity Commission, 1997). The paper describes how I have used an arts-based methodology to begin to open a space for my own necessary sorry work. Others have 
written about the efficacy of the visual in approaching difficult issues in critical autobiography (Camden-Pratt, 2007). I have been involved with academia as a research student and then as an academic for over ten years, and have specialised at times in autobiographical/autoethnographic writing. I was also a high school teacher for around sixteen years. Yet I have never written about my first teaching experience as a white (unqualified) teacher from the city in a Catholic-run Aboriginal boarding school run located in a remote part of Australia. The absence of this story in my writings might be understood as a sort of "inhabited silence" of the sort Lisa Mazzei unravels in her deconstructive work with white teachers in non-white schools in the southern United States (2007). As Mazzei points out, "[s]imply because we were in the minority in our schools did not mean that our whiteness was visible to us: in other words, we still viewed and experienced ourselves as normative and everyone else as Other" (2007, p. 5). She suggests, after Spivak, that the "myopia" of these teachers was shaped by "having been inserted into a history created before we were born" (2007, p. 5). To address this issue, Mazzei develops a strategy for listening to silences in interview data, a deconstructive practice that is "set in motion by something that calls upon and addresses, overtakes (surprises) us and even overwhelms us, to which we must respond, and so be responsive and responsible. Endlessly." (Derrida \& Caputo, 1997, p. 51). This work is just a moment in the "endlessly" that is entailed in deconstruction.

This paper suggests that creative arts responses might open other deconstructive routes. The poststructural paradigm within which I locate my work suggests that there are multiple stories that might be told about any event: that narratives are evoked in particular ways within specific contexts of time, space, and within specific relations of teller and listener (Gannon \& Davies, 2006; Gannon, in press). Within and between the multiple narratives that might be told about any event are also, inevitably, silences. The practice that I discuss here, of inhabiting silence through the visual reworking of narrative data, works into some of these silences. My intention is not to fill silence with words, although I am engaged in that practice by writing here, nor to provide a new truth of my understanding of what was really going on. Rather it is to work into the space between stories differently. Mazzei talks about how poets approach silence differently "not as a tool, nor an extra, but as an essential element in an understanding of meaning and voice" (2007, p. 57). I explore here how nonnarrative visual representation might inhabit silence; might allow ghosts to flicker through the absences implied in the silence.

I began to write about my experiences in this school recently in a collective biography workshop (Davies \& Gannon, 2006) as part of an investigation into pedagogy and place. ${ }^{1}$ In partnership with a number of research colleagues, we worked 
intensively over two weeks to generate stories of our lived experience as teachers and learners at all levels of education and in all sorts of sites. The "pedagogical encounter" came to be our theoretical interest. In relation to my own work, this ethics was further informed by the notion of the face-to-face encounter (Ahmed, 2000; Todd, 2003). I did not begin the workshop with the intention that I would write abut this experience. Rather my story was called up in the relational space of the workshop and the other people, readings, and stories that were in circulation there. I will not tell the stories that I told in the collective biography again here, though my usual inclination is towards story. Instead, I will turn to an art workshop that served as a coda.

A month after the collective biography workshop, we reconvened in the visual arts classroom with two secondary pre-service Visual Arts teachers with whom we had worked on another strand of the Place Pedagogies project. Through a visual mode, rather than my usual written mode, and under their guidance, I entered differently into the time and place that I had begun to evoke again in the collective biography workshop. The face-to-face of the images I created in the workshop were of encounters between myself then and now, as well as between myself and my students. Rather than extending the place stories I had told in the collective biography, the art workshop helped me to create a parallel story-one that was not propelled by the temporality of narrative, perhaps not even of story at all.

I had brought to the workshop photographs taken when I was working at the boarding school. I had also brought in a typed list of the names of students and of places, headed:"Where they come from."There were four pages of class lists on yellowed paper typed more than twenty years ago. They gave me quite a shaky start. I was constrained by the literal qualities of the real names and faces, including myself then, in these artefacts. Even the typeface and the thin texture of the paper surprised me. I could have written more detailed descriptions of many of these children and episodes I remembered from when I was there with them. I had already begun to do this in the collective biography story I had brought with me to the art workshop. But I didn't want to do more of this; indeed, what I had already written had caused me some anxiety. Although I had not previously written about this time I know that it had a profound effect and shaped me as a teacher (and a person) in ways that are difficult to articulate. How could I represent the "me" I was then-straight from the city and the south and the sea of whiteness that was middle class Australia at the timesuddenly engulfed/immersed/embraced by this other Aboriginal Australia? The physicality of these memories astounds me-the children leaning on me, touching me, dark brown skin against skin, suddenly made irrevocably white in this place. Like Mazzei's teachers, my "whiteness was made visible only by its absence in the 
surrounding milieu" (2007, p. 4). The photographs dramatised this. The story that I had told was about both my separation from and difference from the children. What the photos tell is how we were together. Many of them have the young teacher in the middle of groups of children sitting around in different locations in the school. Others are of wall displays in the "Language" classroom where she worked alongside a Christian Brother monk and an Aboriginal teaching aide from one of the communities from where the children had come.

In the art workshop I looked over the photographs and the yellowed list I had forgotten I still had.

\section{Cavefish (Me)}

I began to be freed from the literal truth of the photographic image, and of memory as veridical truth when I started to mask the image rather than elaborate upon it. ${ }^{2}$ I had enlarged each of the photos on a colour photocopier. One of them was of a cave painting. I ignored the two ancestral Wandjina figures-cloud and rain spirits in Aboriginal mythology-that were the main subject of the original photograph and, instead, wrapped and glued the other half of the image across a small canvas. This had been the background to the photo of the Wandjina paintings, the wall of the cave. The wall was covered with paint, layers and layers of ochres of different shades. The outlines of hands could just be seen, and a small, white ghostly image floated amongst all the fragments of other colours. The word for white person in that part of the country is kartiya or ghost. Mazzei too uses the image of a ghost in her work, suggesting that "a deconstructive methodology... (will) invite, encourage, and demand that the specters breach the walls of our commonplace way of hearing (and telling) data" (2007, p. 59).

In the art workshop I painted over the cave wall, dab by dab, with a small brush. When the wall-itself already layers and layers of other people's loving labour over centuries-was entirely covered over by my own work, in shades that ghosted what was underneath, I glued on a tiny cut-out image of myself sitting in the bottom left-hand corner. In the original photograph the figure of the young teacher was sitting amongst a group of her students, looking relaxed and completely immersed in the experience of being there, and in the cluster of bodies that surrounded her. They too were ghosts in this image. Her body still inclined towards them. She was smiling at something one of them had said. 
In the top right-hand corner I drew a fish freehand in ink with a fine black pen, copying it closely from one of the posters I could see in the photographs of the Language classroom. The photograph showed that the pinboards that surrounded the classroom had been divided by strips of paper into panels for each language group. Each panel carried small posters of words and images drawn by students. The name of the fish comes from the Kija language, from a place then called Turkey Creek. Its name in that language is kuntaril. The long sweep down to his eyes and mouth suggested that he might have been a freshwater barramundi-I had caught them too when I had lived there. Another ghost drifted by from my relationships back then and the things we did together. I copied the fish carefully from the poster in the photo and sealed it all over with the gold sheen of shellac.

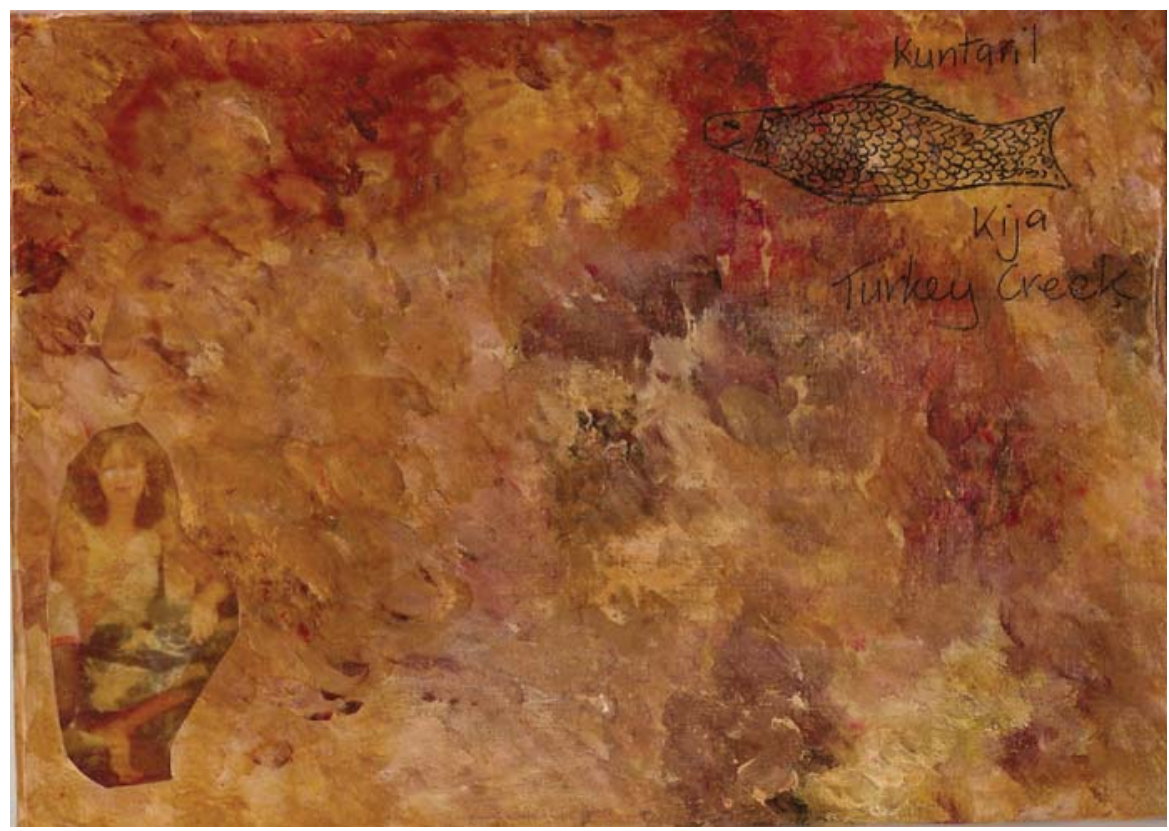

Fig. 1: Cavefish (me)

In this work I became part of the place, rather than separate from it. The subtlety of this image provided me with a new means of thinking into my experience of being there-one that did not flatten out the detail but foregrounded one or two specific elements to represent it. The fish-kuntaril-operates as a sort of metonym. It evokes a string of other associations to do with swimming, with water, with language and with alienation. I drew the fish because he was the most identifiable poster on the wall in the photograph, but he said something more, as well, about 
being there. Although I might have been a fish out of water in some ways, I was also immersed. The strangeness on my tongue now of kuntaril, reminds me that my place there was earned in part by my knowledge of the language. Although I had no teaching qualification I had done some study of Aboriginal languages in the final year of my BA degree, just a year before. I was, and still am, part of the wall of the cave too, with its white ghost haunting the underlayers of the paint and the shellac.

\section{Where They Come From}

For the second artwork, I spent a long time cutting out letters with a blade to try and make a stencil of the lists of place names. They were too many and too long. I realised I did not have the time and that I was still being too literal. But now I had begun to work with the places and their names. I painted a white canvas with white paint and set it aside. Though the list of "Where they come from" was like a mantra, a chant, I didn't yet know what to do with it. I went back to the bodies who in my memory still jostled against my skin. The stories I had told in the collective biography had been about the boys I had taught, but looking again through the photographs I began to remember in more detail, the girls. I cut out the sitting silhouettes of three of the girls I remembered most vividly and screen-printed them on to a strip of brown silk. I used another shade of brown, more like the orange colour of the "pindan" soil of that region. Their silken silhouettes were an absent presence, another sort of ghosting. Repetition was another deconstructive strategy that emerged as I worked (Gannon \& Davies, 2006). These shapes were at ease, with loose limbs and open knees, in contrast to the shapes that my body had made in the photographs at that time.

At the top of the work I stencilled the line: "Where they come from:" though (perhaps like me), it did not quite fit in the space. Underneath, freehand with the black ink pen, I wrote in all the names of the places, all in lower case and butting against each other-a long string of letters that reformed as you looked at them into words: "broomegibbriverstationhallscreekwyndham ..." I put a dot at the end of my list of place names and started listing the names of languages I remembered in the same style. This time the words were not English words laid over Aboriginal country but words from Aboriginal languages with sounds and combinations that are alien to English: "kijanyangumartabardibidyadanga." I began with a rush of joy as if this was what I knew - what I wanted to say-about how special the new knowledge was that I glimpsed there; about ways of being in the world was to me. But I faltered at Bardian extra stroke had accidentally turned it into Bandi and I felt undone. I remembered 
then, after my hand had already inked out the word, that Bidyadanga was not a language name but the Aboriginal name for a particular Catholic Mission community.

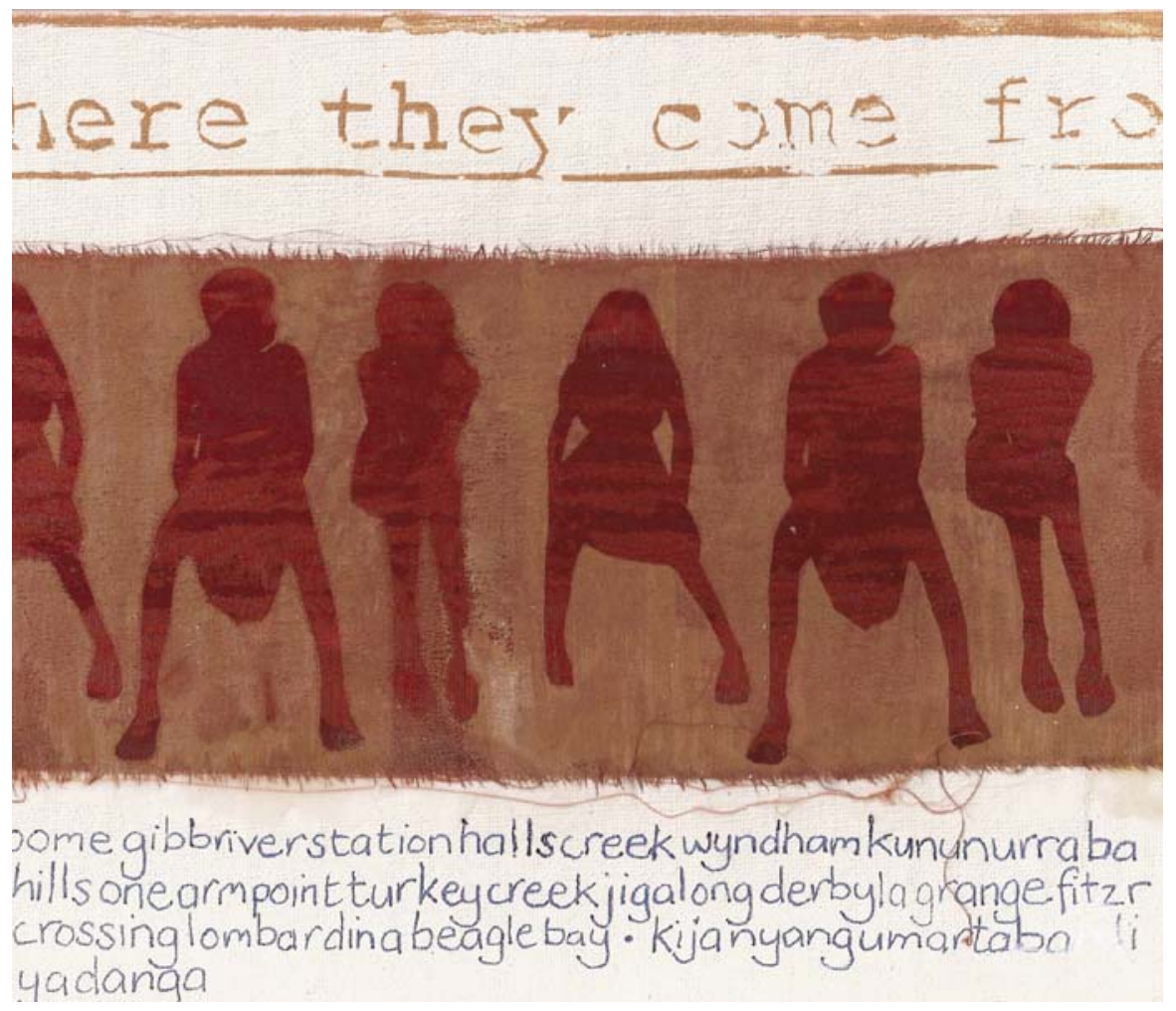

Fig. 2: Where they come from

I remembered how far I was now from where I had been then; how much I had forgotten; how much I didn't know. I only lived there for three years and had only worked at the school for two. I was never as deeply involved with the school or the children as the staff who were practising Catholics. So much of school life had operated on religious rituals about which, as an ex-Catholic, I was ambivalent. After the art workshop I searched online to fill in the gaps in the language names, intending to complete the list of names, to complete the piece, and perhaps, tidy away my memories of the place. On a website documenting the history of the school, I found that I was not mentioned at all. I was an absent presence, a ghost in its official story. Other details I stumbled over in my search disturbed me, a suggestion of other stories I did not know then about one of the men with whom I worked, but, a story which 
had reshaped my understanding of the milieu. I was reminded of my unknowing complicity. I was compelled to resist the impulse to narrative and to closure-to leave the list unfinished, to leave the work incomplete. I am compelled to begin, again, my own sorry story.

\section{Conclusion}

This paper began with an investigation into my earliest memories of teaching through two complementary methodologies. Collective biography, undertaken in a workshop setting with research colleagues, enabled me to retrieve the details of lived experience through telling, writing, and deconstructing stories drawn up from memory (Davies \& Gannon, 2006). At an art workshop that followed, I worked more obliquely with the stories I had retrieved and analysed.Visual arts practice shifted me from narrative logic into a deconstructive space inflected by metonymy, symbolism, and the silences that ghosted the images I had shaped and the experiences I had begun to remember.

In this paper my detailed description of the processes of art making aimed to underline the contingencies of representation and interpretation. The materials that I happened to work with-photographs, lists of names and places, silk of a certain colour, shellac and so on-shaped what I was able to know and to bring forth from my memory. This, too, is an interesting question in arts-based methodologies.

Within the context of my country's long history of abuse of Aboriginal people and of white complicity, marked by Prime Minister's Rudd's "Sorry" speech (February 2008), this paper begins a "Sorry" story of my own: an attempt to inhabit the silence that Mazzei (2007) identifies in her work with white teachers of black children. However, this deconstructive work refuses the settling of any single story or interpretation. Rather, it opens up these long silent stories to a process that is endless, unsettling, and-inevitably-surprising. 


\section{Notes}

1. The collective biography workshop was funded by the Australian Research Council, as was the later art workshop. The ARC Discovery grant, Enabling Place pedagogies in rural and urban Australia, was awarded to M. Somerville, B. Davies, K. Power and S. Gannon, for 2006-2008.

2. Some of the discussion in this section of the paper is based on part of a chapter in Davies and Gannon (forthcoming) Pedagogical Encounters.

\section{References}

Ahmed, S. (2000). Strange encounters: Embodied others in post-coloniality. London, UK: Routledge.

Camden Pratt, C. (2007). Creative arts and critical autobiography: Challenges of blending the deeply personal and the academic in qualitative research. In J. Higgs, A. Titchen, D. Horsfall, \& H. B. Armstrong, (Eds.), Being critical and creative in qualitative research (pp. 248-259). Sydney: Hampden Press.

Davies, B. \& Gannon, S. (Eds.). (2006). Doing collective biography: Investigating the production of subjectivity. Maidenhead, Berkshire, UK: Open University Press/ McGraw Hill.

Derrida, J. \& Caputo, J. (1997). Deconstruction in a nutshell: A conversation with Jacques Derrida. New York: Fordham University Press.

Gannon, S. (In press). Writing narrative. In J. Higgs, D. Horsfall, \& S. Grace (Eds.), Writing qualitative research in practice. Rotterdam, The Netherlands: Sense Publishers.
Gannon, S. \& Davies, B. (2006). Postmodern, poststructural and critical perspectives. In $\mathrm{S}$. Hesse-Biber, \& D. Leckenby (Eds.), Handbook of feminist research: Theory and praxis (pp. 71-106). New York: Sage.

Human Rights and Equal Opportunity Commission (1997). Bringing them home: Report from the national inquiry into the separation of Aboriginal and Torres Strait Islander children from their families. Canberra: Commonwealth of Australia. Retrieved on August 1, 2008, from http://www.austlii.edu.au/au/special/rsjpr oject/rsjlibrary/hreoc/stolen/prelim.html)

Mazzei, L. (2007). Inhabited silence in qualitative research: Putting poststructural theory to work. New York: Peter Lang.

Rudd, K. (2008). Speech. Apology to Australia's indigenous peoples. Retrieved on February 25, 2008 from www.pm.gov.au /media/Speech/2008/speech_0073.cfm

Todd, S. (2003). Learning from the other: Levinas, psychoanalysis and ethical possibilities. New York: SUNY Press. 


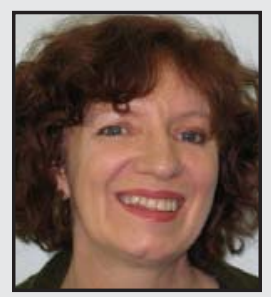

Susanne Gannon is a Senior Lecturer in Education at the University of Western Sydney, Australia. Her interest in artsbased research and creative methodologies has led her to poetry, theatre, and fiction (or vice versa), as well as occasional experiments with visual arts practice. Her book Flesh and the Text: Poststructural Theory and Writing Research (2008) has recently been published and she coedited Doing Collective Biography (2006) with Bronwyn Davies. Their new book, tentatively entitled Pedagogical Encounters, is currently under review. 